\title{
COMPARATIVE STUDY OF ANTIOXIDANT AND ANTICANCER ACTIVITY OF ALPINIA CALCARATA AND ALPINIA GALANGA
}

\author{
VIJAYALAKSHMI MELANATHURU ${ }^{*}$, SUMATHY RENGARAJAN² ${ }^{2}$, NITHYANANDAN THANGAVEL ${ }^{3}$
}

1Department of Biotechnology, Dr. MGR Educational and Research Institute University, Maduravoyal, Chennai, Tamilnadu, India, ${ }^{2}$ Dwaraka Doss Goverdhan Doss Vaishnav College, Arumbakkam, Chennai, Tamilnadu, India, ${ }^{3}$ Department of Genetics, University of Madras, Chennai, Tamilnadu, India

Email: madhushalini2011@gmail.com

Received: 25 Jul 2017 Revised and Accepted: 02 Nov 2017

\section{ABSTRACT}

Objective: The present study was to determine in vitro antioxidant and anticancer activity of Alpinia calcarata and Alpinia galanga.

Methods: The phytochemical screening of rhizome of aqueous extract of Alpinia calcarata and Alpinia galanga was performed using standard procedures. The total phenolic and flavonoid content were determined by Folin-Ciocalteau and Aluminium chloride reagents. The various antioxidant assays and cytotoxic assays (MTT) for Alpinia calcarata and Alpinia galanga was performed using standard methods (DPPH radical scavenging assay, Nitric oxide radical scavenging assay, Reducing power assay, Phosphomolybdenum reduction assay).

Results: The preliminary phytochemical screening of Alpinia calcarata and Alpinia galanga showed the presence of flavonoids, phenols, terpenoids, carbohydrates and proteins. The phenolic content of aqueous extracts of rhizomes of Alpinia calcarata was $454.05 \mu \mathrm{g} / \mathrm{mg}$ and Alpinia galanga was $480.13 \mu \mathrm{g} / \mathrm{mg}$ and was expressed as gallic acid equivalent. The flavonoid content of aqueous extracts of rhizomes of Alpinia calcarata was 36.34 $\mu \mathrm{g} / \mathrm{mg}$ and Alpinia galanga was $67.68 \mu \mathrm{g} / \mathrm{mg}$ and was expressed as quercetin equivalent. In DPPH assay, Alpinia galanga showed $95.36 \%$ whereas Alpinia calcarata showed $54.54 \%$ at $120 \mu \mathrm{g} / \mathrm{ml}$. The maximum NO• radical scavenging activity was $59.44 \%$ for Alpinia calcarata and was $73.10 \%$ for Alpinia galanga at $120 \mu \mathrm{g} / \mathrm{ml}$ concentration. The maximum reducing property was found at the $120 \mu \mathrm{g} / \mathrm{ml}$ of aqueous extract of rhizomes of Alpinia galanga which was higher than the Alpinia calcarata. In Phosphomolybdenum assay, the aqueous extracts of rhizomes of Alpinia calcarata and Alpinia galanga were $55.47 \%$ and $78.38 \%$ respectively. The results of the present investigation indicated that rhizome of aqueous extract of Alpinia galanga showed the highest antioxidant activity in all the assays than Alpinia galanga. The cytotoxicity assay results indicated that rhizome of aqueous extract of Alpinia galanga showed $88.36 \%$ cell viability whereas Alpinia calcarata showed $73.59 \%$ cell viability.

Conclusion: The results obtained in the present study indicate that rhizome of Alpinia galanga are abundant in phenols and flavanoids which may be useful for the development of the anticancer drug.

Keywords: Alpinia galanga, Alpinia calcarata, Antioxidant activity, Anticancer activity

(C) 2017 The Authors. Published by Innovare Academic Sciences Pvt Ltd. This is an open access article under the CC BY license (http://creativecommons.org/licenses/by/4.0/) DOI: http://dx.doi.org/10.22159/ijpps.2017v9i12.21599

\section{INTRODUCTION}

India has a great wealth of medicinal and aromatic plants due to its rich plant diversity. Further, India's unique biogeographical position makes possible the existence of all known types of ecosystems. All the three levels of biodiversity, viz., species diversity, genetic diversity and habitat diversity are found in India. The Indian subcontinent has versatile plant diversity due to its wide-ranging topography and altitudinal differences from sea level to the highest mountain ranges, the immense coastal line in peninsular India, desert in the west, and coolest desert in the eastern regions [1]. The traditional systems of medicine, namely Ayurveda, Siddha and Unani for various herbal preparations use only 2,000 plants out of the total 17,000 flowering plants present. Around 4,500 to 5,000 plant species are utilized by the Indian traditional village physicians, whereas; the oral tradition of the villagers utilizes 5,000 plants for medicinal purposes. In the last decade, for treating various health ailments, the tribe and other traditional communities in India use over 8,000 wild plant species [2].

As $80 \%$ of the population in the world for their primary healthcare still depends on traditional medicines, it clearly denotes the important role played by the traditional medicine in treating various infectious diseases [3]. Around $65 \%$ of the population in rural India for the primary healthcare purpose uses traditional drugs [4]. Researchers reported that for effective conservation of medicinal plants, first and the foremost important condition are to know the status of existing medicinal plant resources [5].

Alpinia calcarata Roscoe (Family: Zingiberaceae), is a rhizomatous herb, which is commonly used in the traditional medicinal systems in Sri
Lanka. Alpinia calcarata rhizomes have a broad spectrum of medicinal properties. The rhizomes of Alpinia calcarata are known to possess antibacterial, anthelmintic, antifungal [6], antioxidant [7]. Aphrodisiac [8], gastroprotective [9], antidiabetic and anticancer activity. Researchers reported that the rhizomes of Alpinia calcarata used to treat high blood pressure, Diuretic, stomach problems, analgesic [10], anticandidal, antiplatelet, antispasmodic [11] antiulcerous hypotensive [12] insecticidal, muscle relaxant and uterine stimulant [13].

Alpinia galanga (L.) (Family: Zingiberaceae is a rhizomatous plant widely distributed in tropical areas and used as a medicine in many countries. The rhizomes of Alpinia galanga is widely used to treat rheumatism, bronchitis, diabetes mellitus and loss of appetite. The various bioactive compounds such as Diarabinoside [14], $\beta=$ steroldiglucosyl caprate [15], Galangoflavonoside [16] and 1Acetoxychavicol acetate [17] have been isolated. The various parts of the plant also show numerous medicinal properties. Leaf extract was shown to exhibit antibacterial activity and wound healing property [18]. The Seeds of Alpinia galanga was found to possess antibacterial activity [19].

The aim of the present investigation was to determine the antioxidant and anticancer activity of rhizome extract of Alpinia calcarata and Alpinia galangal.

\section{MATERIALS AND METHODS}

Collection and authentication of plant materials

The dried rhizomes of Alpinia calcarata and Alpinia galanga were collected from the market at Mylapore, Chennai (Voucher No. A1002 
and A1003) and deposited in Department of Biotechnology, Dr. MGR University, and the rhizomes of plant samples were authenticated by Prof. N. Raaman, Centre for Advanced Studies in Botany, University of Madras, Guindy Campus, Chennai, India

\section{Processing of plant material and preparation of crude extract}

The dried rhizomes of two different medicinal plants were collected, washed under running tap water followed by distilled water and shade dried for $5 \mathrm{~d}$. The dried rhizomes were ground to fine powder and sieved. Approximately $50 \mathrm{~g}$ of finely powdered rhizomes were soaked in $150 \mathrm{ml}$ of distilled water at room temperature for $24 \mathrm{~h}$. The crude extract was filtered using Whatmann No.1 filter paper and then concentrated in vacuum at $40{ }^{\circ} \mathrm{C}-50{ }^{\circ} \mathrm{C}$ (overnight) using a rotary evaporator. The residue was weighed and used for further studies.

\section{Preliminary phytochemical screening}

The rhizomes of aqueous extract Alpinia calcarata and Alpinia galanga was subjected to the qualitative phytochemical screening for the presence of phytoconstituents. Phytochemical test was carried out using standard procedures [21-22].

\section{Determination of total phenolics and total flavonoids content}

The total phenolics content was determined according to the FolinCiocalteu method [22] and the results were expressed as mg gallic acid equivalent/g of dry weight of extract. While the total flavonoids content of the aqueous extract were measured by the method of [23] and the results expressed as mg quercetin equivalent/g dry weight. All tests were performed in triplicate and mean was centered.

\section{Antioxidant activity \\ DPPH radical scavenging activity}

The antioxidant activity of aqueous extract of rhizomes of Alpinia calcarata and Alpinia galanga $(20-120 \mu \mathrm{g} / \mathrm{ml})$ were evaluated through a free radical scavenging effect on 1,1-diphenyl-2-picrylhydrazyl (DPPH) radical. The determination was based on the modified method of [24]. $1 \mathrm{ml}$ of $0.1 \mathrm{mmol}$ DPPH methanolic solution was added into 1 $\mathrm{ml}$ of sample extracts. The mixture was thoroughly mixed and kept in the dark for $30 \mathrm{~min}$. The control was prepared by mixing $1 \mathrm{ml}$ of DPPH and $1 \mathrm{ml}$ methanol. The absorbance was measured at $517 \mathrm{~nm}$ using a spectrophotometer. Percentage of DPPH radical scavenging activity was calculated as follows.

$$
\text { DPPH radical scavenging effect }(\%)=\left(1-A_{s} / A_{c}\right) \times 100
$$

Where $A_{C}$ is the absorbance of the control and $A_{S}$ is the absorbance in the presence of the sample extract or standard

\section{Nitric oxide radical scavenging activity}

Nitric oxide radical scavenging capacity of aqueous extract of rhizomes of Alpinia calcarata and Alpinia galanga was measured according to the method described by [25]. $0.1 \mathrm{ml}$ of sodium nitroprusside $(10 \mathrm{mmol})$ in phosphate buffer $(0.2 \mathrm{M}, \mathrm{pH} 7.8)$ was mixed with a different concentration of aqueous extract $(20-120$ $\mu \mathrm{g} / \mathrm{ml}$ ) and incubated at room temperature for $2 \mathrm{~h}$. After the incubation period, $0.2 \mathrm{ml}$ of Griess reagent (2\% Phosphoric acid, $0.1 \% \mathrm{~N}$-(1-Naphthyl) ethylenediamine dihydrochloride and $1 \%$ Sulfanilamide,) was added. The absorbance was read at $546 \mathrm{~nm}$ against blank. All readings were taken in triplicate and Vitamin C was used as the standard. The \% inhibition of niric oxide scavenging of extract and standard was calculated by the following equation.

$$
\text { Nitric oxide scavenging effect }(\%)=\left(1-\mathrm{A}_{\mathrm{s}} / \mathrm{A}_{\mathrm{c}}\right) \times 100
$$

Where $A_{C}$ is the absorbance of the control and $A_{S}$ is the absorbance in the presence of the sample extract or standard.

\section{Reducing capacity assessment}

The reducing power activity was determined by the spectrophotometric method of [26]. An amount of $20-120 \mu \mathrm{g} / \mathrm{ml}$ of aqueous extract of rhizomes of Alpinia calcarata and Alpinia galanga thoroughly mixed with $2.5 \mathrm{ml}$ of $200 \mathrm{mmol}$ phosphate buffer (pH 6.6) followed by the addition of $2.5 \mathrm{ml}$ of $30 \mathrm{mmol}$ potassium ferricyanide. The mixture was incubated at $50^{\circ} \mathrm{C}$ for $20 \mathrm{~min}$. To the mixture, $2.5 \mathrm{ml}$ of trichloroacetic acid $(600 \mathrm{mmol})$ was added and centrifuged at 3000 rpm for $10 \mathrm{~min} .2 .5 \mathrm{ml}$ of supernatant solution was mixed thoroughly with $2.5 \mathrm{ml}$ of distilled water and $\mathrm{FeCl}_{3}(0.5 \mathrm{ml}, 6 \mathrm{mmol})$. The antioxidants present in the extract results in the reduction of $\mathrm{Fe}^{3+}$ to $\mathrm{Fe}^{2+}$. The Perls Prussian blue colour was observed and read at $700 \mathrm{~nm}$. Vitamin C was used as a positive control.

\section{Phosphomolybdenum reduction assay}

The antioxidant capacity of the aqueous extract of rhizomes of Alpinia calcarata and Alpinia galanga were assessed as described by [27]. The different concentration of aqueous extracts $(20-120 \mu \mathrm{g} / \mathrm{ml})$ was mixed with the reagent solution containing ammonium molybdate $(4 \mathrm{mmol})$, sodium phosphate $(28 \mathrm{mmol})$ and sulphuric acid $(600 \mathrm{mmol})$. The reaction mixture was incubated in a water bath $90^{\circ} \mathrm{C}$ for $90 \mathrm{~min}$. The absorbance of the coloured complex was measured at $695 \mathrm{~nm}$. The appropriate solutions of ascorbic acid have been used as a standard reference. Increased the absorbance of the reaction mixture indicates the increase in phosphomolybdenum reduction.

\section{Anticancer activity \\ Cell line and culture}

Human liver cancer HepG2 cell line was obtained from National centre for cell sciences Pune (NCCS). The cells were maintained in Minimal Essential Media supplemented with 10\% FBS, Penicillin $(100 \mathrm{U} / \mathrm{ml})$, and Streptomycin $(100 \mu \mathrm{g} / \mathrm{ml})$ in a humidified atmosphere of $50 \mu \mathrm{g} / \mathrm{ml} \mathrm{CO}_{2}$ at $37^{\circ} \mathrm{C}$.

\section{Chemicals}

Minimal essential medium (MEM) was purchased from Hi-Media Laboratories Fetal bovine serum (FBS) was purchased from Cistron laboratories Trypsin, methyl thiazolyl diphenyl-tetrazolium bromide (MTT), and Dimethyl sulfoxide (DMSO) were purchased from (Sisco research laboratory chemicals Mumbai). All of other chemicals and reagents were obtained from Sigma Aldrich, Mumbai.

\section{In vitro assay for cytotoxicity activity (MTT assay)}

The Cytotoxicity of extracts on HepG2 cells was determined by the MTT assay [28]. Cells $\left(1 \times 10^{5} /\right.$ well $)$ were plated in $1 \mathrm{ml}$ of medium/well in 24-well plates. After $48 \mathrm{~h}$ incubation, the cell reaches the confluence. Then, cells were incubated in the presence of various concentrations of the samples in $0.1 \%$ DMSO for $48 \mathrm{~h}$ at 37 ${ }^{\circ} \mathrm{C}$. After removal of the sample solution and washing with phosphate-buffered saline ( $\mathrm{pH} 7.4), 200 \mu \mathrm{l} /$ well $(5 \mathrm{mg} / \mathrm{ml})$ of $0.5 \%$ 3-(4,5-dimethyl-2-thiazolyl)-2,5-diphenyl--tetrazolium bromide cells (MTT) phosphate-buffered saline solution was added. After $4 \mathrm{~h}$ incubation, $0.04 \mathrm{M} \mathrm{HCl}$ /isopropanol was added. Viable cells were determined by the absorbance at $570 \mathrm{~nm}$. Measurements were performed and the concentration required for a $50 \%$ inhibition of viability (IC50) was determined graphically. The absorbance at 570 $\mathrm{nm}$ was measured with a UV-Spectrophotometer using wells without sample containing cells as blanks. The effect of the extracts on the proliferation of liver cancer cells was expressed as the \% cell viability, using the following formula:

$\%$ cell viability $=$ A570 of treated cells $/$ A570 of control cells $\times 100 \%$

\section{RESULTS AND DISCUSSION}

Phytochemical analysis of aqueous extract of rhizomes of Alpinia calcarata and Alpinia galanga

The preliminary phytochemical screening of rhizomes of aqueous extracts was done to assess the presence bioactive components. The secondary metabolites are commonly called as phytochemicals that possess strong antioxidant activity and might play an important role in preventing colossal oxidative damage. The secondary metabolites are usually classified through their biosynthetic pathways and are divided into three large families: alkaloids, terpenes and steroids, and phenolic compounds [29]. They are mainly found in storage tissues rather than in vegetative ones, due to their high biological potency [30]. The results of aqueous extracts of rhizomes of Alpinia calcarata and Alpinia galanga were showed the presence of terpenoids, phenols, and flavonoids as shown in table 1 . The present study was correlated with the previous report, the ethanolic extract of Alpinia calcarata and 
Alpinia speciosa showed the presence of alkaloids, flavonoids, phenols, steroids, tannins, proteins and carbohydrates. It was investigated that flavonoids present in Alpinia calcarata and Alpinia speciosa rhizomes have excellent antioxidant activities and are important bioactive components in rhizomes which can cause inhibition of the oxidative modification of the human lipoprotein [31].

Table 1: Preliminary phytochemical test of rhizome of aqueous extracts of Alpinia calcarata and Alpinia galanga

\begin{tabular}{llll}
\hline S. No. & Test & Alpinia calcarata & Alpinia galanga \\
\hline 1 & Carbohydrates & + & + \\
2 & Proteins & + & + \\
3 & Aminoacids & - & + \\
4 & Alkaloids & + & - \\
5 & Flavanoids & + & + \\
6 & Steriods & + & - \\
7 & Tannins & + & - \\
8 & Terpenoids & - & + \\
9 & Saponins & + & - \\
10 & Phenols & - & - \\
11 & Glycosides & & + \\
\hline
\end{tabular}

+Indicates Positive Result; --Indicates Negative Result

Total phenol and flavonoid content of aqueous extracts of rhizomes of Alpinia calcarata and Alpinia galanga

Phenolics are the most widespread secondary metabolite in the plant kingdom. These diverse groups of compounds have received much attention as a potential natural antioxidant in terms of their ability to act as both efficient radical scavengers and a metal chelator. It has been reported that the antioxidant activity of phenol is mainly due to their redox properties, hydrogen donors and singlet oxygen quenchers [32]. The various studies prove that dietary phenolic compounds have a great role in preventing neurodegenerative disorders [33]. Therefore, in the present study, total phenolic content present in the extract was estimated using modified Folin-ciocalteau method and flavonoid content was estimated by $\mathrm{AlCl}_{3}$ method. The phenolic content of aqueous extracts of rhizomes of Alpinia calcarata was $454.05 \mu \mathrm{g} / \mathrm{mg}$ and Alpinia galanga was $480.13 \mu \mathrm{g} / \mathrm{mg}$ and was expressed as gallic acid equivalent. The flavonoid content of aqueous extracts of rhizomes of Alpinia calcarata was $36.34 \mu \mathrm{g} / \mathrm{mg}$ and Alpinia galanga was 67.68 $\mu \mathrm{g} / \mathrm{mg}$ and was expressed as quercetin equivalent (table 2 ).

Table 2: Total phenol and flavonoid content of aqueous extracts of rhizomes of Alpinia calcarata and Alpinia galanga

\begin{tabular}{lll}
\hline Medicinal plants & Total phenolic content (GAE) $\boldsymbol{\mu g} / \mathbf{m g}$ & Total Flavanoid content (QE) $\boldsymbol{\mu g} / \mathbf{m g}$ \\
\hline Alpinia calcarata & 454.05 & 36.34 \\
Alpinia galanga & 480.13 & 67.68 \\
\hline
\end{tabular}

GAE-gallic acid equivalent, QE-quercetin equivalent

\section{DPPH radical scavenging assay}

In this present study, the antioxidant activity of aqueous extracts of rhizomes of Alpinia calcarata and Alpinia galanga were investigated by using DPPH radical scavenging assay. The DPPH antioxidant assay is based on the ability of DPPH, a stable free radical, to decolourize in the presence of antioxidants. DPPH has the advantage of being unaffected by certain side reactions, such as metal ion chelation and enzyme inhibition brought by various additives. A freshly prepared DPPH solution exhibits a deep purple colour generally disappears when antioxidants present in the medium. Thus the antioxidants present in the extract can quench DPPH free radicals by donating hydrogen atom or by electron transfer and convert them to the colourless product (2,2-diphenyl-1picrylhydrazyl, or a substituted analogous hydrazine, resulting in a decreasing absorbance at the $517 \mathrm{~nm}$ [34]. The mixture of $1 \mathrm{ml}$ methanol and $1 \mathrm{ml}$ of DPPH solution is used as a control. The aqueous extracts of rhizomes of Alpinia calcarata and Alpinia galanga were exhibited significant dose-dependent inhibition of DPPH activity. The DPPH radical inhibition was $54.54 \%$ and $95.36 \%$ at $120 \mu \mathrm{g} / \mathrm{ml}$ concentration (table 3). The result are correlated with previous studies that methanolic extract of Alpinia galanga showed effective inhibition of $67.78 \%$ DPPH antioxidant activity in a dosedependent manner. The antioxidants present in the rhizome extract can acts as radical scavengers may protect the cells against various diseases such as cancer, neurodegenerative disorders [35].

Table 3: DPPH radical scavenging assay of rhizomes of Alpinia calcarata and Alpinia galanga

\begin{tabular}{lll}
\hline Medicinal plants & Aqueous extract $(\boldsymbol{\mu g} / \mathbf{m l})$ & DPPH radical scavenging activity \\
\hline Alpinia calcarata & 20 & $13.06 \pm 1.54$ \\
& 40 & $30.11 \pm 2.40$ \\
& 60 & $42.04 \pm 5.62$ \\
Alpinia galanga & 80 & $46.02 \pm 3.47$ \\
& 120 & $54.54 \pm 4.43$ \\
& 20 & $35.05 \pm 2.14$ \\
& 40 & $54.63 \pm 4.18$ \\
& 60 & $71.64 \pm 3.03$ \\
80 & $86.59 \pm 3.96$ \\
\hline
\end{tabular}

aResults are expressed as \% of DPPH radical scavenging activity with respect to control. Each value represents mean \pm SD of the three determinants $(n=3)$ 


\section{Nitric oxide (NO·) radical scavenging activity}

In this spectrophotometric method, the absorbance of chromophore formed during the diazotization of the nitrile with sulphanilamide and the subsequent coupling with naphthyl ethylenediamine dihydrochloride was measured. NO, being a potent pleiotropic mediator in physiological processes and a diffusible free radical in the pathological conditions reacts with superoxide anion and form a potentially cytotoxic molecule, the peroxynitrite (ONOO). Its protonated form, peroxynitrous acid ( $\mathrm{ONOOH})$, is a very strong oxidant. The main route of damage is the nitration or hydroxylation of aromatic compounds, particularly tyrosine. Under physiological conditions, peroxynitrite also forms an adduct with carbon dioxide dissolved in body fluid and responsible for oxidative damage of proteins in living systems. Nitric oxide (NO) is a chemical mediator and is involved in the regulation of various physiological processes generated by endothelial cells, neurons, macrophages, etc [36]. The maximum NO radical scavenging activity was $59.44 \%$ for Alpinia calcarata and was $73.10 \%$ for Alpinia galanga at $120 \mu \mathrm{g} / \mathrm{ml}$ concentration (table 4). Nitric oxide is generated in biological tissues by specific nitric oxide synthases [37]. The results correlated with the previous report showed that the ethanolic extract of Alpinia calcarata rhizome (EEACR) showed $72.89 \%$ of nitric oxide radical scavenging activity [38]. The previous literature reported that the significant radical scavenging activity may be due to the presence of antioxidant activity of flavanoid, which competes with $\mathrm{O}_{2}$ and finally reacts with NO, leading to the lesser production of nitric oxide formation [39].

Table 4: Nitric oxide scavenging assay of rhizomes of Alpinia calcarata and Alpinia galanga

\begin{tabular}{lll}
\hline Medicinal plants & Aqueous extract $(\boldsymbol{\mu g} / \mathbf{m l})$ & Nitric oxide scavenging activity \\
\hline Alpinia calcarata & 20 & $12.22 \pm 2.99$ \\
& 40 & $23.21 \pm 3.67$ \\
& 60 & $35.87 \pm 4.69$ \\
Alpinia galanga & 80 & $49.31 \pm 2.43$ \\
& 120 & $59.44 \pm 3.65$ \\
& 20 & $16.25 \pm 3.46$ \\
& 40 & $29.81 \pm 3.18$ \\
& 60 & $47.34 \pm 2.55$ \\
& 80 & $59.22 \pm 3.12$ \\
\hline
\end{tabular}

${ }^{a}$ Results are expressed as $\%$ of Nitric Oxide scavenging activity with respect to control. Each value represents mean \pm SD of the three determinants $(n=3)$

\section{$\mathrm{Fe}^{3+}$ reducing power assay}

The reducing power assay method is quantitative and hence it is expressed as ascorbic acid equivalents. The aqueous extracts of rhizomes of Alpinia calcarata and Alpinia galanga were exhibited significant dose-dependent reducing power activity. The presence of reductants/antioxidants in aqueous extracts of rhizomes of Alpinia calcarata and Alpinia galanga extracts causes the reduction of the $\mathrm{Fe}^{3+} /$ ferricyanide complex to the ferrous form $\left(\mathrm{Fe}^{2+}\right)$. Therefore, the $\mathrm{Fe}^{2+} \mathrm{can}$ be monitored by measuring the formation of Perl's Prussian blue at $700 \mathrm{~nm}$. The maximum reducing property was found at the $120 \mu \mathrm{g} / \mathrm{ml}$ of aqueous extract of rhizomes of Alpinia galanga which was higher than the Alpinia calcarata (fig. 1). Researchers reported that phenolic compounds play a major role in scavenging free radicals by electron-transfer mechanism [40]. The reducing capacity of an extract may serve as a significant indicator of its potential antioxidant activity [41]. Researchers proved that the methanolic extract of Alpinia pahangensis showed the highest reductive activity due to the presence of antioxidants present in the rhizome extract of Alpinia pahangensis. The reducing power of the extract increased with the increase in the concentration of the extract until it reaches a certain level and then become constant. Basically, reducing power is associated with the presence of reductones that break the free radical chain by donating a hydrogen atom [42].

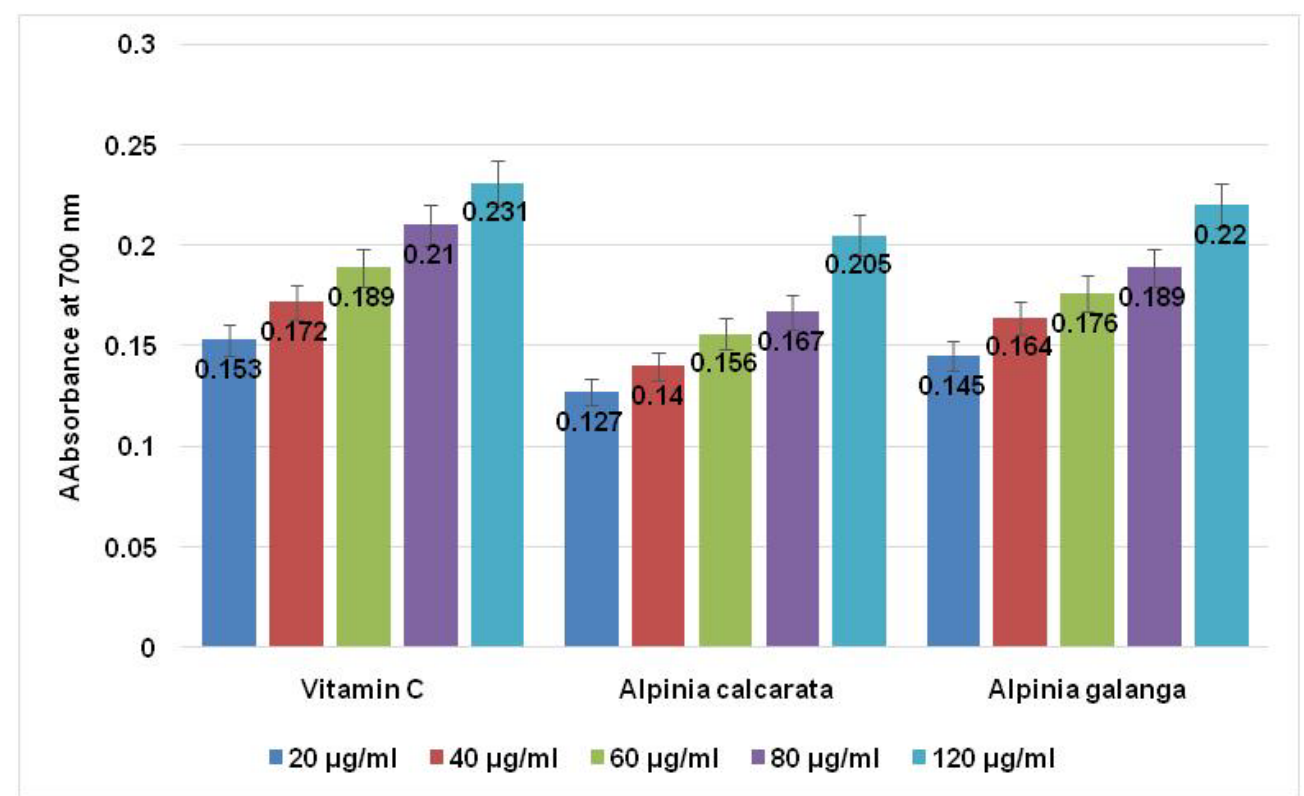

Fig. 1: Effect of rhizome of aqueous extract on reducing power activity of Alpinia calcarata and Alpinia galanga. The values represent the mean \pm SD of three determinants $(n=3)$ 


\section{Phosphomolybdenum reduction assay}

Phosphomolybdenum assay revealed that aqueous extracts of rhizomes of Alpinia calcarata and Alpinia galanga have relatively potent reducing power. In the presence of a reducing agent, reduction of phosphomolybdic acid to phosphomolybdate blue $\left(\mathrm{Mo}^{+6}\right.$ to $\left.\mathrm{Mo}^{+5}\right)$ was observed [43]. The phosphomolybdenum assay method is expressed as ascorbic acid equivalents. In the concentration range from $20-120 \mu \mathrm{g} / \mathrm{ml}$ concentration, the aqueous extracts of rhizomes of Alpinia calcarata and Alpinia galanga showed strong dose-dependent reducing activity.
The result obtained was confirmed by the high potency of the aqueous extract towards the transition metal ions. The aqueous extracts of rhizomes of Alpinia calcarata and Alpinia galanga were $55.47 \%$ and $78.38 \%$ respectively (table 5 ). Increase in absorbance of the reaction mixture indicates that the increase in reduction capacity of the extract. Antioxidants with DPPH radical scavenging activity donate hydrogen to free radicals, mainly lipid peroxides or hydroperoxide radicals that are the major propagators of the chain autoxidation of lipids, and to form non-radical species, resulting in the inhibition of propagating phase of lipid peroxidation [44].

Table 5: Phosphomolybdenum reduction assay of rhizomes of Alpinia calcarata and Alpinia galanga

\begin{tabular}{lll}
\hline Medicinal plants & Aqueous extract $(\boldsymbol{\mu g} / \mathbf{m l})$ & Phosphomolybdenum reduction assay \\
\hline Alpinia calcarata & 20 & $14.32 \pm 2.20$ \\
& 40 & $24.16 \pm 2.43$ \\
60 & $38.16 \pm 3.57$ \\
& 80 & $43.95 \pm 3.29$ \\
Alpinia galanga & 120 & $55.47 \pm 4.08$ \\
& 20 & $23.53 \pm 2.38$ \\
& 40 & $45.27 \pm 2.66$ \\
& 60 & $57.30 \pm 4.21$ \\
& 80 & $65.29 \pm 4.82$ \\
& 120 & $78.38 \pm 5.13$ \\
\hline
\end{tabular}

aResults are expressed as \% of Phosphomolybdenum reduction asssay with respect to control. Each value represents mean \pm SD of three determinants $(\mathrm{n}=3)$

\section{Anticancer activity of aqueous extract of rhizomes of Alpinia calcarata and Alpinia galanga}

The cytotoxic effect of aqueous extract of rhizomes of Alpinia calcarata and Alpinia galanga against human liver cancer cell line HepG2 was determined by a rapid colourimetric assay using MTT (methylthiazolyl-tetrazolium bromide) assay. In this study, rhizome aqueous extracts were tested for anticancer activity by MTT assay on HepG2 cell line. Measurements were performed and the concentration required for a $50 \%$ inhibition of viability ( $\mathrm{IC}_{50}$ ) was determined (fig. 2). The cytotoxic effect of rhizome aqueous extracts of HepG2 cells was expressed as the \% cell viability. The morphology of HepG2 cells progressively changed from $7.8 \mu \mathrm{g} / \mathrm{ml}$ to $1000 \mu \mathrm{g} / \mathrm{ml}$ concentration of the extract and was compared with control. The maximum cell death was $73.59 \%$ for Alpinia calcarata and was $88.36 \%$ for Alpinia galanga was observed against human liver cancer cell line HepG2 cell line (fig. 3 and 4). The previous study suggests that the cytotoxicity of Alpinia purpurata extract on HeLa was evaluated by MTT assay based on a percentage of cell viability. The n-Hexane extract was found to have cytotoxic effect against HeLa, showing cell proliferation inhibition in a concentration-dependent manner. The IC50 for $A$. purpurata crude extract was found to be $41.25 \mu \mathrm{g} / \mathrm{ml}$ [45].

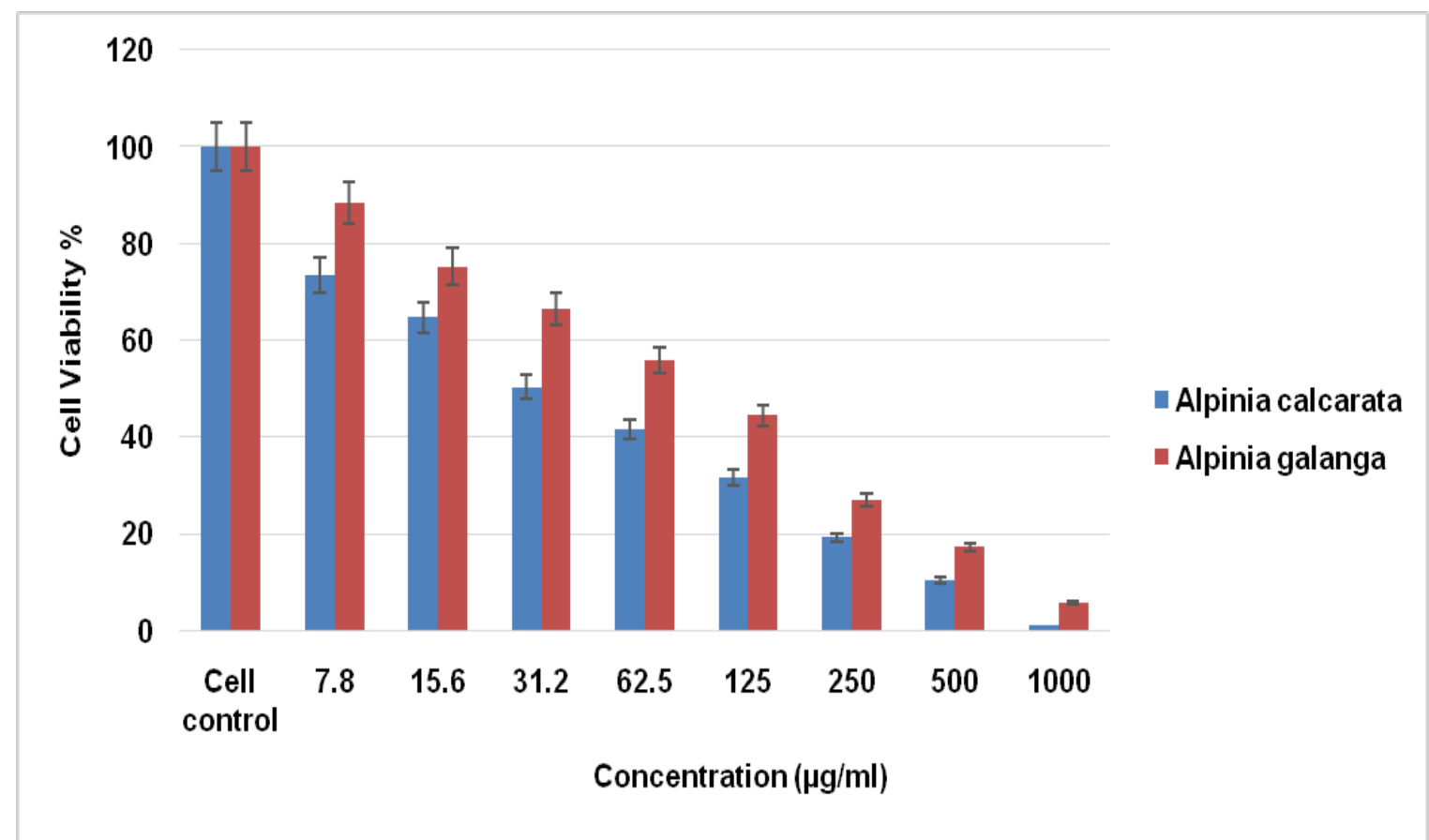

Fig. 2: Anticancer effect of the rhizome of aqueous extract of Alpinia calcarata and Alpinia galanga against HepG2 Human liver cancer cell line. Each data represents the mean from three independent experiments (mean \pm SD) 


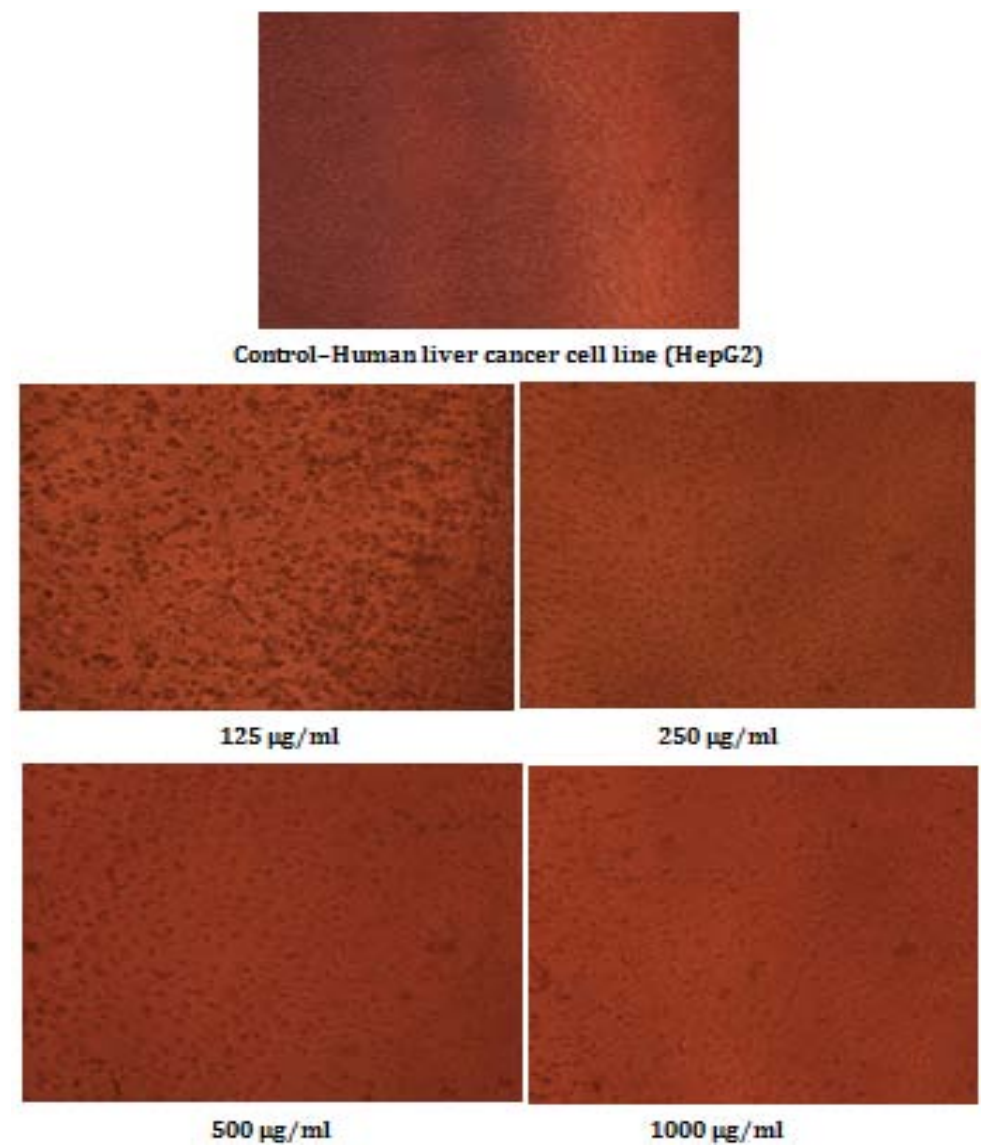

Fig. 3: Microscopic view of HepG2 cells of control and treated cells with aqueous extract of Alpinia calcarata. The morphology of HepG2 cells progressively changed from $7.8 \mu \mathrm{g} / \mathrm{ml}$ to $1000 \mu \mathrm{g} / \mathrm{ml}$ concentration of the extract and was compared with control

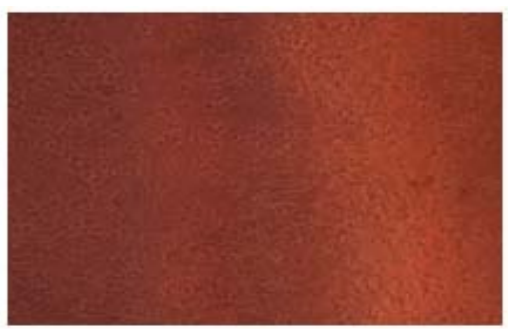

Control-Human liver cancer cell line (HepG2)

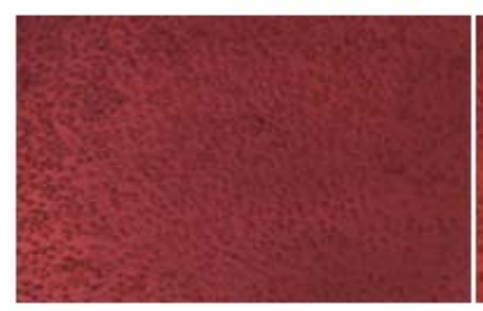

$125 \mu \mathrm{g} / \mathrm{ml}$

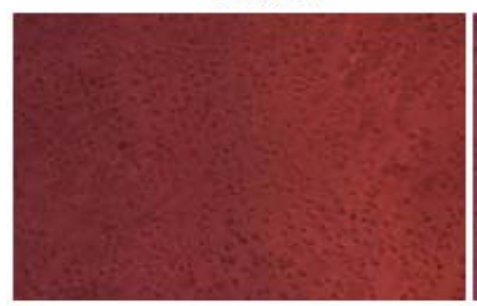

$500 \mu \mathrm{g} / \mathrm{ml}$

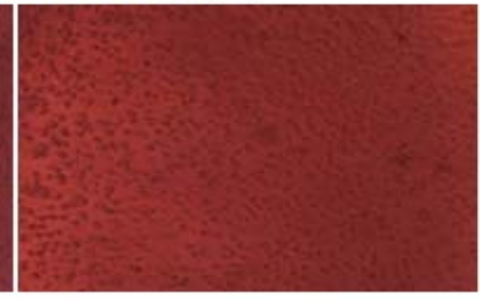

$250 \mu \mathrm{g} / \mathrm{ml}$

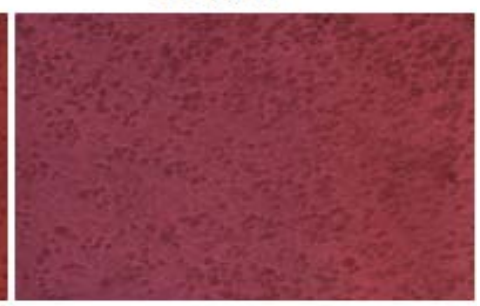

$1000 \mu \mathrm{g} / \mathrm{ml}$

Fig. 4: Microscopic view of HepG2 cells of control and treated cells with aqueous extract of Alpinia galanga. The morphology of HepG2 cells progressively changed from $7.8 \mu \mathrm{g} / \mathrm{ml}$ to $1000 \mu \mathrm{g} / \mathrm{ml}$ concentration of the extract and was compared with control 


\section{CONCLUSION}

Phytochemical screening of aqueous extracts Alpinia calcarata and Alpinia galanga rhizomes had revealed the presence of flavonoids, terpenoids, phenols, carbohydrates and proteins. The results of the present investigation indicate that Alpinia galanga rhizome extract exhibited the highest antioxidant activity in all the assays than Alpinia calcarata. The effect of aqueous extract of HepG2 cells are expressed as $\%$ cell viability. The results indicated that rhizome of aqueous extract of Alpinia galanga showed $88.36 \%$ cell viability whereas Alpinia calcarata showed $73.59 \%$ cell viability. Further investigation to be done for the identification of bioactive compounds from Alpinia galanga for the development of the anticancer drug.

\section{ACKNOWLEDGEMENT}

The authors are thankful to Armats biotek research center for the support and encouragement throughout the study.

\section{AUTHORS CONTRIBUTION}

The design of the research work was done by the first author Dr. Vijayalakshmi Melanathuru. The experimental part of the work and writing of the manuscript was done by the corresponding author Dr. Sumathy rengarajan. The correction and the revision of the manuscript were done by Mr. Nithyanandan Thangavel.

\section{CONFLICT OF INTERESTS}

\section{Declared none}

\section{REFERENCES}

1. Sharma SC, Goel AK. The need for ex-situ conservation of endangered plants from tropical India. Botanic Gardens Conservation News 1990;1:16-9.

2. Narula A, Srivastava PS, Rangaswamy NS. In vitro cultures studies on Dioscorea species. J Tro Med Plants 2000;1:60-74.

3. Owolabi J, Omogbai EKI, Obasuyi O. Antifungal and antibacterial activities of the ethanolic and aqueous extract of Kigelia africana (Bignoniaceae) stem bark. Afr J Biotech 2007;6:882-5

4. Anonymous. Traditional medicine Strategy Report, World Health Organization, Rome; 1992.

5. Robbers JE, Tyler VE. Herbs of choice-the therapeutic use of phytomedicines. Int J Phrm Sci 2002;3:199-203.

6. Arambewela LSR, Arambewela LDAM, Ratnasooriya WD. Antinociceptive activities of aqueous and ethanolic extracts of Alpinia calcarata rhizomes in rats. J Ethanopharmacol 2004;95:311-6.

7. Arambewela LSR, Arambewela LDAM. Antioxidant activities of Ethanolic and hot aqueous extracts of Alpinia calcarata rhizomes. Aust J Med Herbalism 2005; 17:91-4.

8. Ratnasooriya WD, Jayakody JR. Effects of aqueous extract of Alpinia calcarata rhizomes on the reproductive competence of male rats. Acta Biol Hung 2006;57:23-35.

9. Arambewela LSR, Arambewela LDAM, Ratnasooriya WD. Effect of Alpinia calcarata rhizomes on ethanol-induced gastric ulcers in rats. Phcog Mag 2009;4:226-31.

10. Leal-Cardoso JH. Effects of essential oil of Alpinia Zerumbet on the compound action potential of the rat sciatic nerve. Phytomed 2004;11:549-53.

11. Bezerra MA. Myorelant and antispasmodic effects of the essential oil of Alpinia speciosa rat ileum. Phytother Res 2000;14:549-51.

12. Lahlou S, Interaminense LF, Leal-Cardoso JH, Duarte GP. Antihypertensive effects of the essential oil of Alpinia Zerumbet and its main constituent, terpinen-4-ol, in DOCA-salt hypertensive conscio rats. Fundam Clin Pharmacol 2003;17:323-30.

13. De Moura RS. Antihypertensive and endothelium-dependent vasodilator effects of Alpinia Zerumbet, a medicinal plant. J Cardiovasc Pharmacol 2005;46:288-94.

14. Fuloria NK, Fuloria S. Isolation of $\beta$-sitosterol diarabinoside from rhizomes of Alpinia galanga. World Acad Sci Eng Technol 2012;72:1455-7.

15. Jaju SB, Indurwade NH, Sakarkar DM, Fuloria NK, Ali MD, Basu SP. Isolation of $\beta$-sitosterol diglucosyl caprate from Alpinia galanga. Pharma Res 2010;2:264-6.
16. Jaju SB, Indurwade NH, Sakarkar DM, Fuloria NK, Ali MD, Das S, et al. Galangoflavonoid isolated from rhizome of Alpinia galanga (L) Sw (Zingiberaceae). Trop J Pharm Res 2009;8:545-50.

17. Seo J, Cho S, Park S, Lee E, Lee J, Han S, et al. 1_-Acetoxychavicol acetate isolated from rhizomes Alpinia galanga ameliorates ovalbumin-induced asthma in mice. Plos One 2013;8:e56447.

18. Reddy JL, Jose B, Ruveena TN. Evaluation of antibacterial activity of the seed essential oil and leaf extracts of Alpinia galanga (L.) Willd. Asian J Biochem Pharma Res 2011;3:270-6.

19. Deepa S, Prabakaran G. Wound healing activity of ethanolic extract of Alpinia galanga leaves. J Bio Innovation 2012;1:120-6.

20. Harborne JB. Phytochemical methods: a guide to modern techniques of plant analysis chapman and hall. London, Ltd; 1973. p. $149-88$.

21. Trease GE, Evans IC. Textbook of Pharmacognosy. $12^{\text {th }}$ edn. Balliere Tindall, London; 1983.

22. Bao JS, Cai YZ, Sun MG, Wang, Corke H. Anthocyanins, flavonols, and free radical scavenging activity of Chinese bayberry (Myrica rubra) extracts and their color properties and stability. Agric Food Chem 2005;53:2327-32.

23. Sultana B, Anwar F, Przybylski R. Antioxidant activity of phenolic components present in barks of Azadirachta indica, Terminalia Arjuna, Acacia nilotica, and Eugenia jambolana Lam Trees. Food Chem 2007;104:1106-14.

24. Akowuah GA, Ismail Z, Norhayati I, Sadikun A. The effects of different extraction solvents of varying polarities on polyphenols of Orthosiphon stamineus and evaluation of the free radical-scavenging activity. Food Chem 2005;93:311-7.

25. Athukorala Y, Kim KN, Jeon YJ. Antiproliferative and antioxidant properties of an enzymatic hydrolysate from brown alga, Ecklonia cava. Food Chem Toxicol 2006;44:1065-74.

26. Olabinri BM, Odedire OO, Olaleye MT, Adekunle AS, Ehigie LO, Olabinri PF. In vitro evaluation of hydroxyl and nitric oxide radical scavenging activities of artemether. Res J Biol Sci 2010;5:102-5.

27. Prieto P, Pineda M, Aguilar M. Spectrophotometric quantitation of antioxidant capacity through the formation of a phosphomolybdenum complex: specific application to the determination of vitamin E. Anal Biochem 1999;269:337-41.

28. Mosmann T. Rapid colourimetric assay for cellular growth and survival: application to proliferation and cytotoxicity tests. J Immunol Methods 1983;65:55-63.

29. Bougard F, Gravot A, Milesi S, Gontier E. Production of plant secondary metabolites: a historical perspective. Plant Sci 2001;161:839-51.

30. Walton NJ, Brown DE. Chemicals from plants: perspectives on plant secondary products; Imperial College Press: London; 1999.

31. Swapana N, Jotinkumar T, Devi CB, Singh MS, Singh SB. Total phenolic, total flavonoid contents and antioxidant activity of a few indigenous, Fruits Grown in Manipur. Bio-Scan 2012;7:73-6.

32. Rice-Evans CA, Miller NJ, Paganga G. Structure-antioxidant activity relationships of flavonoids and phenolic acids. Free Radical Biol Med 1996;20:933-56

33. Ramassamy C. Emerging role of polyphenolic compounds in the treatment of neurodegenerative diseases: a review of their intracellular targets. Eur J Pharmacol 2006;545:51-64.

34. Yamaguchi T, Takamura H, Matoba T, Terao J. HPLC method for evaluation of the free radical scavenging activity of foods by using 2, 2-diphenyl-1-picrylhydrazyl. Biosci Biotechnol Biochem 2002;62:1201-4.

35. Wong LF, Lim YY, Omar M. Antioxidant and antimicrobial activities of some Alpinia species. J Food Biochem 2009;33:835-51.

36. Lata H, Ahuja GK. Role of free radicals in health and disease. Indian J Physiol Allied Sci 2003;57:124-8.

37. Alam MN, Bristi NJ, Rafiquzzaman M. Review on in vivo and in vitro methods evaluation of antioxidant activity. Saudi Pharm J 2013;21:143-52.

38. Majidul I, Rumana Y, Hanif A, Polash CK, Ayshasiddeka FI, Rowshanul $\mathrm{H}$, et al. Antioxidant activity of ethanolic extract of Alpinia calcarata Rosc. Rhizome J Pharma Phytochem 2017;6:469-74.

39. Alasalvar C, Karamac M, Amarowicz R, Shahidi F. Antioxidant and antiradical activities in extracts of hazelnut kernel 
(Corylusa vellana L.) and hazelnut green leafy cover. J Agric Food Chem 2006;54:4826-32.

40. Ak T, Gulcin I. Antioxidant and radical scavenging properties of curcumin. Chem Biol Interact 2008;174:27-7.

41. Arunkumar K, Chandrashekar KR. Phytochemical evaluation and in vitro antimicrobial and antioxidant studies of leaf and stem bark extracts of Polyalthia fragans (Dalz) bedd-an endemic species of Western Ghats. Int J Pharma Pharm Sci 2017;9:20-4.

42. Duh PD. Antioxidant activity of burdock (Arctium lappa Linne): its scavenging effect on free radical and active oxygen. J Am Oil Chem Soc 1998;75:455-61.
43. Prieto P, Pineda M, Anguilar M. Spectrophotometric quantitation of antioxidant capacity through the formation of a phosphomolybdenum complex: specific application to the determination of vitamin E. Anal Biochem 1999;269:337-41.

44. Loo AY, Jain K, Darah I. Antioxidant activity of compounds isolated from the pyroligneous acid, Rhizophora apiculata. Food Chem 2008;107:1151-60.

45. Enock KO, Palanirajan A, Deivasigamani M, Chinthamony A, Velliyur KG. Antioxidant, cytotoxic and apoptotic activities of crude extract of Alpinia purpurata on cervical cancer cell line. Int J Pharm Sci Rev Res 2016;36:28-34. 